\title{
Melanocortin-4 receptor and leptin as genes for the selection of superior Madrasin cattle
}

\author{
Budi Utomo, Rimayanti Rimayanti, Indah Norma Triana and Amaq Fadholly (D) \\ Division of Veterinary Reproduction, Faculty of Veterinary Medicine, Universitas Airlangga, Surabaya, 60115, \\ Indonesia. \\ Corresponding author: Budi Utomo,e-mail: budi_reprovet@yahoo.com \\ Co-authors: RR: rimayanti@fkh.unair.ac.id, INT: indah-n-t@fkh.unair.ac.id, AF: amaqfadholly95@gmail.com \\ Received: 15-08-2021, Accepted: 24-11-2021, Published online: 31-12-2021
}

doi: www.doi.org/10.14202/vetworld.2021.3224-3228 How to cite this article: Utomo B, Rimayanti R, Triana IN, Fadholly A (2021) Melanocortin-4 receptor and leptin as genes for the selection of superior Madrasin cattle, Veterinary World, 14(12): 3224-3228.

\begin{abstract}
Background and Aim: The genetic improvement of cattle through livestock section is based on quantitative, qualitative, and molecular characteristics. This study examined polymorphisms of the melanocortin-4 receptor (MC4R) and leptin genes as a reference for the selection of superior breeds in Madrasin cattle.

Materials and Methods: The leptin and MC4R genes of Madrasin cattle were amplified using polymerase chain reaction (PCR); then, restriction fragment length polymorphism of the leptin gene was performed using the restriction enzyme BsaA1, at site 2793 with ACGT point position.

Results: The leptin gene was divided into three bands, namely, AA with one fragment (522 bp), CG with two fragments (441 bp and $81 \mathrm{bp}$ ), and AG with three fragments (522 bp, $441 \mathrm{bp}$, and $81 \mathrm{bp}$ ). The MCR-4 gene was divided into three bands, namely, $493 \mathrm{bp}, 318 \mathrm{bp}$, and $175 \mathrm{bp}$.

Conclusion: The MC4R and leptin genes can act as molecular markers for growth traits in Madrasin cattle and can be used to genetically optimize and improve growth. The GG allele of the MC4R gene and the AA allele of the leptin gene can be used in Madrasin cattle.
\end{abstract}

Keywords: leptin, Madrasin, melanocortin-4 receptor.

\section{Introduction}

Because of its great variety of plant and animal species, including cattle genetic resources, Indonesia has very high biodiversity (mega biodiversity). Several breeds of cattle, both local and exotic, are well distributed within the country. The Madura cattle, a cross between the wild Bos and Bos javanicus breeds, are popular because of their uniform shape. The deoxyribonuclease acid (DNA) of the Madura breed is a mixture of the Zebu cow and bull. Meanwhile, in several areas on Madura Island, artificial insemination is being used aggressively to cross local and Limousine cattle to produce offspring known as Limura; this community is known for crossing local and exotic breeds in hopes of producing highly productive calves [1,2].

Melanocortin-4 receptor (MC4R) is the primary gene responsible for regulating food intake and energy balance. MC4R is a pair of $\mathrm{G}$ protein receptors expressed in the hypothalamic nucleus, as it also plays an important role in the regulation of homeostasis. The protein regulates behavior related to food intake and

Copyright: Utomo, et al. Open Access. This article is distributed under the terms of the Creative Commons Attribution 4.0 International License (http://creativecommons.org/licenses/ by/4.0/), which permits unrestricted use, distribution, and reproduction in any medium, provided you give appropriate credit to the original author(s) and the source, provide a link to the Creative Commons license, and indicate if changes were made. The Creative Commons Public Domain Dedication waiver (http:// creativecommons.org/publicdomain/zero/1.0/) applies to the data made available in this article, unless otherwise stated. energy expenditure; it is responsible for the obesity response to leptin in vertebrates, including humans [3]. The gene also produces synthesized leptin from adipose tissue. This hormone plays an important role in controlling body weight, feed intake, and energy balance. Furthermore, polymorphisms in the MC4R and leptin genes affect body weight and intramuscular fat deposition in supporting efforts, which can increase the productivity of Limura cattle [4]. However, this type of study is lacking in Madrasin cattle.

This study examined polymorphisms of MC4R and leptin genes as a reference for the selection of superior breeds in Madrasin cattle.

\section{Materials and Methods}

\section{Ethical approval}

The study was approved by Animal Care and Use Committee of Veterinary of Medicine Faculty, Universitas Airlangga (reference number: 1.KE.200.03.2021).

\section{Study period and location}

This study was conducted from March 2021 to September 2021 at Center of Veterinary, Bali, Indonesia.

\section{Sample collection}

Semen samples were obtained from Madrasin bulls, ranging in age from 2-4 years. Before semen collection, the preputial hairs were clipped, and the orifice was washed with clean water and then dried 
with clean paper towel to minimize contamination. DNA samples were obtained from the semen.

\section{DNA extraction}

A total of 10 million sperm cells $/ \mathrm{mL}$ were extracted through the spin column method, using theQiAamp DNA Mini Kit (Qiagen, Canada), according to the manufacturer's instructions. The total DNA was then stored in a freezer at $-20^{\circ} \mathrm{C}$ until further analysis.

\section{PCR amplification}

Using the duplex PCR method, the total extracted sperm DNA was further amplified at a volume of $25 \mu \mathrm{L}$, which contained $12.5 \mu \mathrm{L}$ GoTaq Green Master Mix (Promega, USA), $1 \mu \mathrm{L}$ primer F (10 pmol), $1 \mu \mathrm{L}$ primer $\mathrm{R}(10 \mathrm{pmol}), 8.5 \mu \mathrm{L}$ nuclease-free water (Promega), and $2 \mu \mathrm{L}$ DNA samples. The two pairs of primers used were forward 5'- GTCGGGCGTCTTGTTCATC-3' and reverse 5'-GCTTGTGTTTAGCATCGCGT-3' [5]. Moreover, amplification was conducted using a PCR (Applied Biosystem, USA) machine, which consisted of pre-denaturation, denaturation, annealing, and extension at $94^{\circ} \mathrm{C}, 94^{\circ} \mathrm{C}, 58^{\circ} \mathrm{C}$, and $72^{\circ} \mathrm{C}$ for $5 \mathrm{~min}$, and 30,30 , and $30 \mathrm{~s}$, with 45 repeated cycles, respectively. The cycle ended with a final extension of $72^{\circ} \mathrm{C}$ for $10 \mathrm{~min}$, followed by a hold at $4^{\circ} \mathrm{C}$

Amplification of the exon 3 region of the leptin gene used forward L1 (5'-GTCTGGAGGCAAAG GGCAGAGT-3'). Pre-denaturation, denaturation, annealing, and extension at $94,94,64$, and $72^{\circ} \mathrm{C}$ were conducted for $5 \mathrm{~min}$, and 30, 30, and $30 \mathrm{~s}$, with 45 repeated cycles, respectively. The cycle ended with a final extension of $72^{\circ} \mathrm{C}$ for $10 \mathrm{~min}$, accompanied by a hold at $4^{\circ} \mathrm{C}$.

\section{PCR-restriction fragment length polymorphism (PCR-RFLP)}

PCR products (amplified specific MC4R DNA fragments [493 bp] and leptin [580 bp] genes) were digested with HpyCH4IV (restriction enzyme) and single-nucleotide polymorphisms (SNPs) g.1133C > $\mathrm{G}$. The RFLP process was carried out at a total volume of $20.3 \mu \mathrm{L}$, consisting of $2.8 \mu \mathrm{L}$ DDW, $2 \mu \mathrm{L} 10 \times$ buffer, $0.5 \mu \mathrm{L}$ HpyCH4IV, and $15 \mu \mathrm{L}$ PCR product, which were further incubated at $37^{\circ} \mathrm{C}$ for $5 \mathrm{~h}$ through a multiheater. The digestion results were electrophoresed on $4 \%$ agarose gel, and staining was conducted by adding $1 \mu \mathrm{L}$ ethidium bromide to $50 \mathrm{ml}$ of $1 \times$ Tris/Borate/ EDTA solution. The final result was observed visually using an ultraviolet transilluminator.

\section{Electrophoresis}

The PCR products were analyzed through electrophoresis on 1.5\% agarose gel with SYBR dye (Invitrogen S7563, USA). Molecular markers (Invitrogen) measuring $100 \mathrm{bp}$ were also added to determine the size of the PCR products. Furthermore, the results were observed using a gel documentation system (Bio-Rad, USA).

\section{Statistical analysis}

The allele and genotype frequencies of each sample were calculated following the measurement of unidirectional pattern variance.

\section{Results}

\section{Amplification of the leptin and MC4R genes}

To amplify the leptin and MC4R genes, DNA material was isolated from 15 samples of Madrasin cattle blood. The electrophoretic results showed that the genes amplified to 522 (leptin) and 493 (MC4R) bp, as shown in Figures-1 and 2, respectively. These results indicated that the leptin and MC4R genes can be amplified through PCR.

\section{PCR-RFLP of the leptin and MC4R genes}

RFLP or DNA cutting of the leptin gene was conducted at site 2793, through the BsaA1 (restriction enzyme) and $\mathrm{AC} \mid \mathrm{GT}$ cut point position. We obtained 15 genetic samples of the hormone, divided into three bands of 522, 441, and $81 \mathrm{bp}$. Based on Figure-3, the leptin gene had three genotypes, namely, AA, GG, and AG, with one, two, or three fragments (corresponding to $522 \mathrm{bp} ; 441$ and $81 \mathrm{bp} ; 522,441$, and $81 \mathrm{bp}$ ). Furthermore, the restriction enzymes recognized the leptin gene at the cutting site because the DNA sequence did not undergo any mutations. The results of the PCR-RFLP for the leptin gene are shown in Figure-3.

Fifteen samples of the MC4R gene were obtained, divided into three bands of 493, 318, and 175 bp. Moreover, the GG, CG, and CC genotypes originated from the cattle whose blood was analyzed using the PCR-RFLP method. In addition, the GG and CG genotypes had two and three DNA fragments at 175 and 318 bp and at 175, 318, and 493 bp,

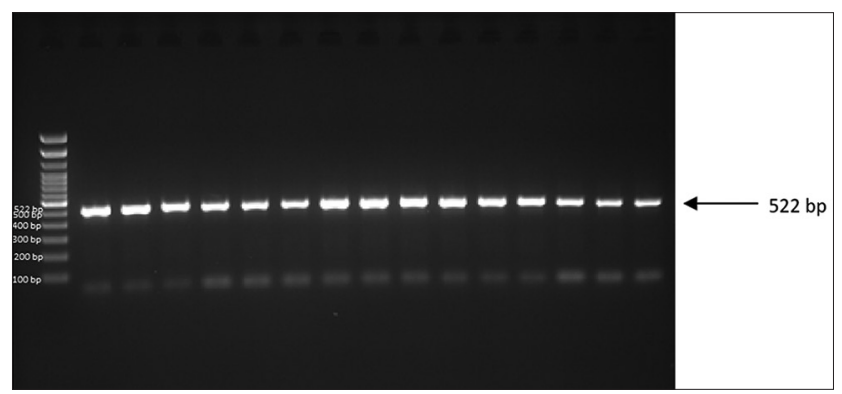

Figure-1: Leptin gene amplification on Madrasin cattle.

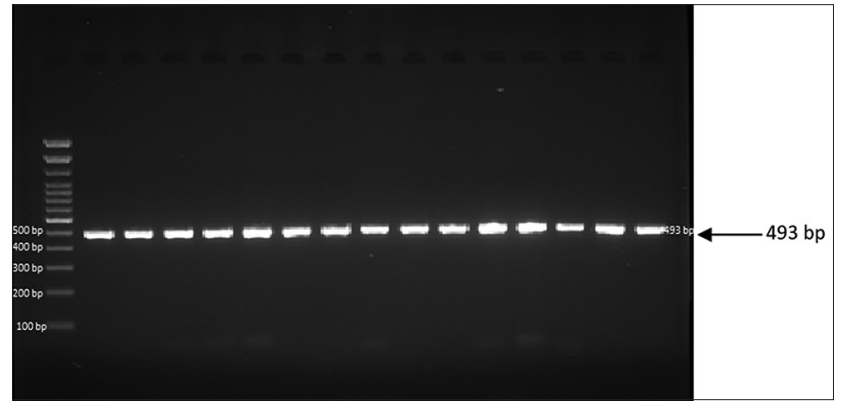

Figure-2: Melanocortin-4 receptor gene amplification of Madrasin cattle. 
respectively, whereas the $\mathrm{CC}$ genotype had one large fragment at $493 \mathrm{bp}$ (Figure-4).

\section{Discussion}

Genotyping is the process of identifying genotypes in individuals through DNA markers at a specific locus within the genome [6]. Genotyping results are often used to describe the distribution of alleles within a population based on observations of genetic diversity. Genotyping is also used to determine the population balance, according to the HardyWeinberg equilibrium. Based on the DNA markers of a target gene, results can be used to describe the genotype of each animal under investigation [7]. Genotypic determinations are often conducted using PCR-RFLP.

Polymorphisms in several portions of the leptin gene have the potential to be used for molecular selection; these polymorphisms are reportedly associated with body and carcass weights, milk protein content, backfat thickness, and rib-eye areas [8-10]. Polymorphism in intron 2 is also associated with milk production $[11,12]$, body and carcass backfat thickness, and empty period [13-15]. Meanwhile, polymorphisms in intron 2 do not correlate with adult weight in Iraqi local and Fries Holstein (exotic) cattle. The leptin gene polymorphism in exon 2 is further associated with carcass weight, chest circumference, thick back fat, milk production, and

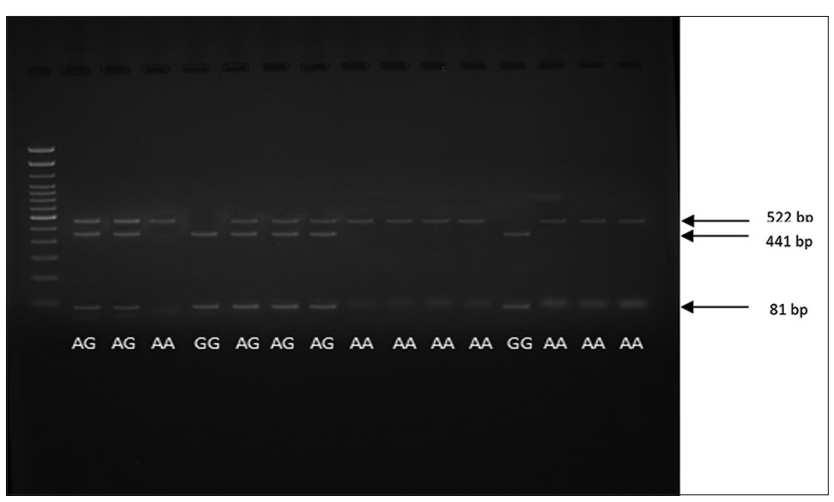

Figure-3: Leptin gene polymerase chain reactionrestriction fragment length polymorphism with restriction enzyme BsaA1.

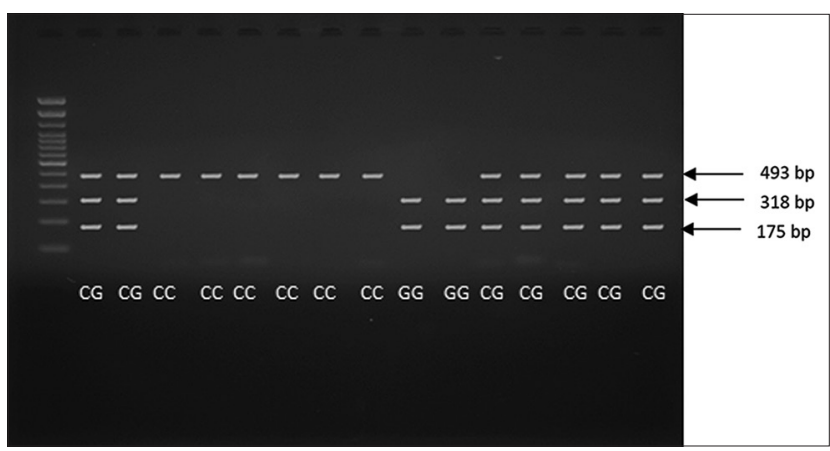

Figure-4: Melanocortin-4 receptor gene polymerase chain reaction-restriction fragment length polymorphism with HpyCH4IV restriction enzyme. feed intake [16-18]. In exon 3, polymorphisms are correlated with body and carcass weights, marbling score, and non-return rate [19]. Furthermore, mutations in the exon portion of the gene cause changes in certain amino acids, affecting livestock productivity. For example, a mutation in the g. $1233 \mathrm{C}>\mathrm{T}$ position within the Lep/BamHI gene causes arginine to be exchanged with cysteine. It is associated with chest circumference in Anatolian Black cattle. A mutation in the g.1863C $>\mathrm{T}$ position in the Lep/HphI gene (exon 2) also causes alanine to be changed to valine but is not associated with productivity; this lack of effect on productivity is due to the two amino acids being located in the $\beta$ helix of leptin. Although alanine and valine are similar types of protein (non-polar aliphatic $\mathrm{R}$ group), they do not induce changes in the receptor structure [20]. Mutations at positions g.820C $>\mathrm{T}$ and g.2270A $>\mathrm{G}(\mathrm{Lep} / \mathrm{Sau} 3 \mathrm{AI})$ in Sistani (Bos indicus) cattle are associated with weaning weight. However, they should be further examined in B. indicus breeds in Indonesia (e.g., the Ongole, Aceh, and Madura species). Moreover, mutations at g. $252 \mathrm{~T}>\mathrm{A}$, g. $1127 \mathrm{~A}>\mathrm{T}$, g. $1233 \mathrm{C}>\mathrm{T}$, and g.14911 (Lep/ClaI, Lep/BspDI, Lep/BamHI, and Lep/MspI), as well as their effect on the productivity of $B$. indicus and $B$. javanicus cattle, also require further examination $[21,22]$.

Leptin gene utilization was carried out by identifying the genotype in a livestock population, since selected cattle should meet the standards of good farming practices, for the expression of their genetic potential. Our results showed that the leptin gene had three genotypes, namely, AA, GG, and AG with one, two, or three fragments. The genotypic data were associated with livestock productivity (assuming a large number of cows were evaluated). In beef cattle, when the heterozygous genotype $(\mathrm{AB})$ leads to the best average performance, that animal should be used for the feedlot. The high performance of this genotypic attribute is caused by the effect of heterosis (hybrid vigor), which indicates that the capabilities of offspring are higher than those of their parents [23]. Therefore, stocking homozygous cattle (AA and $\mathrm{BB}$ ) are necessary to have sources for the production of heterozygous $(\mathrm{AB})$ breeds. When two similar average (AA and $\mathrm{AB}$ ) and one low (BB) performance genotypes are obtained, the $\mathrm{AB}$ and $\mathrm{BB}$ individuals should be culled; cattle with $A B$ genotypes are still excluded and not used as breed sources, due to having poor performance B allele traits. However, AA individuals are utilized to produce feeders.

MC4R gene plays an important role in regulating food intake and body weight in native Korean cattle (brown, striped, and black) [24]. Due to mutations, the gene encoding this receptor contributes to obesity. The MC4R gene acts as an adrenocorticotropic hormone, as well as an alpha-beta- and gamma-melanocyte-stimulating hormone (MSH), which plays an important role in energy homeostasis and somatic 
growth, or as a receptor on the heptapeptide nucleus. Somatic growth has an important role in cattle development and is controlled by a complex system. The genes carrying out somatic growth are responsible for cattle development after birth. The MC4R gene acts on energy homeostasis mediated by alpha-MSH [25]. Our data showed that GG and CG genotypes had two and three DNA fragments, whereas the CC genotype had one large fragment. MC4R-C1069G is an SNP in various cattle breeds due to being associated with fat thickness, as well live and carcass weights [26]. Furthermore, cattle with the GG genotype have higher economic characteristics and better growth than GC and CC genotypes. In Korean cattle, the GG genotype of the Luxi breed also has better economic features than those with the CC genotype. The live and carcass weights, as well as the backfat thickness of cattle with the GG genotype, were higher than those of the CG and CC genotypes [26]. Similar results have also been noted in adult Hanwoo cattle, with higher live and body weight values attributed to the GG genotype. In addition, the GG genotype of the PO Kebumen breed has a higher birth length $(66.34 \pm 6.73 \mathrm{~cm})$ than the CC $(65.43 \pm 7.21 \mathrm{~cm})$ and $\mathrm{GC}(59.47 \pm 5.77 \mathrm{~cm})$ genotypes $[27,28]$.

\section{Conclusion}

The use of the MC4R and leptin genes as molecular markers was applied to optimize and improve the genetic quality of Madrasin cattle growth. Moreover, the GG (MC4R) and AA (leptin) alleles of both genes were found to be good sources for breeding. The MC4R and leptin genes can act as molecular markers for growth traits in Madrasin cattle and can be used to optimize genetically and improve growth. The GG allele of the MC4R gene and the AA allele of the leptin gene were found in Madrasin cattle.

\section{Authors' Contributions}

BU: Designed and performed the study. BU and RR: Provided materials and critical reviews. BU, RR, INT, and AF: Literature search and manuscript preparation. All authors read and approved the final version of the manuscript.

\section{Acknowledgments}

This study was funded by Penelitain Unggulan Perguruan Tinggi research grant of Universitas Airlangga, Indonesia, with reference number 144/ DRPM/04/2021.

\section{Competing Interests}

The authors declare that they have no competing interests.

\section{Publisher's Note}

Veterinary World remains neutral with regard to jurisdictional claims in published institutional affiliation.

\section{References}

1. Utomo, B., Putranto, E.D. and Fadholly, A. (2020) Profile of follicle-stimulating hormone and polymorphism of follicle-stimulating hormone receptor in Madrasin cattle with ovarian hypofunction. Vet. World, 13(5): 879-883.

2. Konig, E.Z., Mirkena, T., Standberg, E. and Audho, J. (2016) Participation definition of breeding objectives for sheep breeds under pastoral systems-the case of red Massai and Dorper sheep in Kenya. Trop. Anim. Health Prod., 48(1): 1-12.

3. Zhang, C.L., Wang, Y.H., Chen, H., Lan, X.Y., Lei, C.Z. and Fang, X.T. (2009) Association between variants in the 50- untranslated region of the bovine MC4R gene and two growth traits in Nanyang cattle. Mol. Biol. Rep., 36(1): 1839-1843.

4. Polini, B., Maltese, P.E. and Ciondolo, I.D. (2016) Prevalence of mutations in LEP, LEPR, and MC4R genes in individuals with severe obesity. Genet. Mol. Res., 15(3): 201-209.

5. Seong, J., Lee, H.K., Suh, D.S., Kong, H.S. and Park, H.D. (2012) Identification and analysis of MC4R polymorphisms and their association with economic traits of Korean cattle (Hanwoo). Mol. Biol. Rep., 39(4): 3597-3601.

6. Ciptadi, G., Nasich, M., Budiarto, A., Nuryadi and Nurgiatiningsih, V.M.A. (2021) The estrus synchronization response following $\mathrm{PGF}_{2} \alpha$ treatment in Indonesia Madura cattle with different body condition scores. Pak. Vet. J., 32(4): 624-626.

7. Siswijono, S.B., Nurgiartiningsih, V.M.A., Nugroho, B.A., Fanani, Z. and Winarno, P.S. (2017) Analysis towards promoting and inhibiting factors in bull semen selection of AI cattle in Madura. Res. J. Pharm. Biol. Chem., 8(4): 866-870.

8. Casarini, L. and Crepieux, P. (2019) Molucular mechanisms of action of FSH. Front Endocrinol. (Lausanne), 10(1): 305-315.

9. Law, N.C., Donaubauer, E.M., Zeleznik, A.J. and HunzickerDunn, M. (2017) How protein kinase A activates canonical tyrosine kinase signalling pathways to promote granulosa cell differentiation. Endocrinology, 158(7): 2043-2051.

10. Siegel, E.T., Kim, H.G., Nishimoto, H.K. and Layman, L.C. (2013) The molecular basis of impaired follicle-stimulating hormone action. Reprod. Sci., 20(3): 211-233.

11. Yan, Y., Gong, Z., Zhang, L., Li, Y., Li, X., Zhu, L. and Sun, L. (2013) Association of follicle-stimulating hormone receptor polymorphisms with ovarian response in Chinese women: A prospective clinical study. PLoS One, 8(1): e78138.

12. Cheng, Y., Huang, C. and Tsai, H. (2016) Relationship of bovine $\mathrm{NOS}_{2}$ gene polymorphisms to the risk of bovine tuberculosis in Holstein cattle. J. Vet. Med. Sci., 78(2): 281-286.

13. Raschia, M.A., Nani, J.P., Maizon, D.O., Beribe, M.J., Amadio, A.F. and Poli, M.A. (2018) Single nucleotide polymorphisms in candidate genes associated with milk yield in Argentinean Holstein x Jersey cows. J. Anim. Sci. Technol., 60(1): 31-41.

14. Leven, J.S.E. (2019) Follicle-stimulating hormone receptor (GSHR) polymorphisms and polycystic ovary syndrome (PCOS). Front. Endocrinol. (Lausanne), 10(1): 23-32.

15. Zhang, Y., Guo, G., Huang, H., Lu, L., Wang, L., Fang, L., Liu, L., Wang, Y. and Zhang, S. (2015) Screening for JH1 genetic defect carriers in Jersey cattle by a polymerase chain reaction and restriction fragment length polymorphism assay. J. Vet. Diagn. Investig., 27(5): 596-599.

16. Roper, L.K., Briguglio, J.S., Evans, C.S., Jackson, M.B. and Chapman, E.R. (2015) Sex-specific regulation of follicle-stimulating hormone secretion by synaptotagmin 9. Nat. Commun., 6(1): 8645.

17. Yao, Y., Ma, C., Tang, H. and Hu, Y. (2011) Influence of follicle-stimulating hormone receptor (FSHR) Ser680Asn polymorphism on ovarian function and 
in-vitro fertilization outcome: A meta-analysis. Mol. Genet. Metabol., 103(4): 388-393.

18. Balogh, O., Szepes, O., Kovacs, K., Kulcsar, M., Reiczigel, J., Alcazar, J.A., Keresztes, M., Febel, H., Bartyik, J., Fekete, G., Fesus, L. and Huszenicza, G. (2008) Interrelationships of growth hormone AluI polymorphism, insulin resistance, milk production and reproductive performance in Holstein-Friesian cows. Vet. Med., 53(11): 604-616.

19. Yang, W.C., Li, S.J., Tang, K.Q., Hua, G.H., Zhang, C.Y., Yu, J.N., Han, L. and Yang, L.G. (2010) Polymorphisms in the 5 upstream region of the FSH receptor gene and their association with over superovulation traits in Chinese Holstein cows. Anim. Reprod. Sci., 119(3-4): 172-177.

20. Hartatik, T. (2017) Sequence analysis and identification of allele distribution of melanocortin 1 receptor (MC1R) gene in Indonesia cattle (Bos sondaicus x Bos indicus). Asian J. Anim. Sci., 31(1): 40-46.

21. Sharifiyazdi, H., Mirzaei, A. and Ghanaaian, Z. (2018) Characterization of polymorphism in the FSH receptor gene and its impact on some reproductive indices in dairy cows. Anim. Reprod. Sci., 188(1): 45-50.

22. Arslan, K., Akyuz, B. and Agaoglu, O.K. (2015) Investigation of STAT5A, FSHR and LHR gene polymorphisms in Turkish indigenous cattle breeds (East Anatolian red, South Anatolian red, Turkish grey, Anatolian black, and Zavot). Russ. J. Genet., 51(11): 1088-1095.

23. Gaviria, S.M., Herrera, A.L. and Zuuaga, J.J.E. (2016)
Association between FSHR polymorphism with productive and reproductive traits in Antioquia Holstein cattle. Rev. Fac. Nad. Agron., 69(1): 7793-7801.

24. Weller, M.M.D., Fortes, M.R.S., Porto-Neto, L.R., Kelly, M., Venus, B., Kidd, L., Rego, J.P.A., Edwards, S., Boe-Hensen, G.B., Piper, E., Lehnert, S.A., Guiaraes, S.E.F. and Moore, S.S. (2016) Candidate gene expression in Bos indicus tissue: Prepubertal and postpubertal heifers in diestrus. Front. Vet. Sci., 3(1): 94.

25. Arslan, K., Akyuz, B., Akcay, A., Ilgar, E.G., Macun, H.C. and Cinar, M.U. (2017) Association of number of artificial inseminations per pregnancy in Holstein dairy cows with polymorphism in luteinizing hormone receptor and follicle-stimulating hormone receptor genes. Slov. Vet. Res., 54(1): 91-98

26. Hernandez-Cruz, B.C., Cervantes-Acosta, P., MontielPalacios, F., Canseco-Sedano, R. and Carrasco-Garcia, A. (2009) Allelic variants of FSHR gene in cows of different genotypes in Mexico. J. Anim. Vet. Adv., 8(12): 2489-2494.

27. Ilgaz, N.S., Aydos, O.S.E., Karadag, A., Taspinar, M., Eryilmaz, O.G. and Sunguroglu, A. (2015) Impact of follicle-stimulating hormone receptor variants in female infertility. J. Assist. Reprod. Genet., 32(11): 1659-1668.

28. Huang, X., Li, L., Hong, L., Zhou, W., Shi, H., Zhang, H., Zhang, Z., Sun, X. and Du, J. (2015) The Ser680Asn polymorphism in the follicle-stimulating hormone receptor gene is associated with the ovarian response in controlled ovarian hyperstimulation. Clin. Endocrinol. (Oxf), 82(4): 577-583. 